\title{
NADOC and the National Aborigines Day in Sydney, 1957-67
}

\section{Jonathan Bollen and Anne Brewster}

This article presents an account of the events organised in Sydney by the National Aborigines Day Observance Committee (NADOC) in its first decade, 1957-67. While committees operated in other states, the NADOC in New South Wales was the most prominent in those years. ${ }^{1}$ The significance of NADOC, or NAIDOC as it is has been known since the 1970s, is evident in the organisation's survival. It has developed into Australia's largest annual celebration of the 'history, culture and achievements of Aboriginal and Torres Strait Islander peoples'. ${ }^{2}$ Yet there exists to date only a brief historical account of its development. ${ }^{3}$

NADOC was one of a number of organisations active in mid-twentieth-century Australia, involving Aboriginal and white Australians. As a church-based organisation with a close relationship to government, NADOC emerged alongside the AboriginalAustralian Fellowship (AAF), founded by Faith Bandler and Pearl Gibbs in 1956, and the Federal Council for Aboriginal Advancement (FCAA), founded in 1958. ${ }^{4}$ Like the Indigenous members of the FCAA, many of the Indigenous participants in the NADOC events, we argue, understood themselves as 'bearers of collective rights'. ${ }^{5}$ They expressed these rights in discourse addressed to white Australians. They also drew on an artistic repertoire of poetry, music, storytelling and performance. In his history of the Australian Aboriginal Progressive Association (AAPA), founded in the 1920s, John Maynard emphasises the skills of Aboriginal activists in oratory

\footnotetext{
J. Rogalsky to Spalding, 7 August 1962, SLNSW, MLMSS 4057.

National NAIDOC Secretariat 2017.

Aboriginal and Torres Strait Islander Commission 2003.

Bandler and Fox 1983; Taffe 2005.

Rowse 2005: 18.
} 
and rhetoric. ${ }^{6}$ Similar skills were deployed by Indigenous participants in the NADOC events. Maynard also records that AAPA conferences featured 'musical entertainments' given by Aboriginal performers, and members proposed an 'old time native display' for presentation to touring royalty. ${ }^{7}$ We argue, in this article, that the events organised by NADOC provided an important platform for Indigenous participation and cultural production in the public sphere.

In researching NADOC's first decade of events in Sydney, we examine the interplay of two contesting imperatives: (1) the advocacy of assimilation as a policy that 'expected' all Aboriginal people to 'attain the same manner of living as other Australians', and promoted the 'acceptance' of Aboriginal people 'by the whole Australian community'; ${ }^{8}$ and (2) the involvement of Indigenous participants, their negotiation of the policy of assimilation, and their insistence on Aboriginal difference, continuity and survival. NADOC aligned with the federal policy of assimilation in distributing government-produced publications that sought to improve nonIndigenous Australian attitudes towards Aboriginal people. Anna Haebich analyses these publications as propaganda, part of the government's exercise in public relations to promote the policy of assimilation. ${ }^{9}$ Alongside government publications, committee documents and media reports, we draw on photographs of participants performing at NADOC's Sydney events. ${ }^{10}$ These we analyse for indications of cultural repertoire, affective relations and audience significance aspects that are not always evident in written documents from government and church sources. ${ }^{11}$ Our analysis of the Aboriginal speakers, singers and writers who participated in NADOC's first decade suggests that they claimed Indigenous agency: they wrested control over discourse and repertoire in performance, they deployed Indigenous aesthetics and shared Indigenous knowledge. Their participation challenged the prevailing characterisation of Aboriginal people as submissive subjects of white governance and passive consumers of European practices and products.

\footnotetext{
6 Maynard 2007.

7 Maynard 2007: 74, 90-92.

8 Department of Territories 1961b. Various actors, both individual and institutional, evoked, deployed and critiqued the government's cultural definition of assimilation throughout the first decade of NADOC (see Attwood 2003: 193-211). The meaning of the term was not stable; Rani Kerin borrows from Charles Rowley to characterise assimilation as 'nebulous' and 'vaguely defined', varying in its meaning from 'general equality' to biological absorption (Kerin 2005: 85.1).

9 Haebich 2008: 137-58.

10 Many of the photographs were taken for Dawn, a magazine for Aboriginal people published by the NSW Aborigines Welfare Board, 1952-69; these photographs are now part of the Government Printing Office series at the State Library of NSW. We also draw on images from Fairfax taken for the Sydney Morning Herald.

11 Taylor 2003.
} 


\section{The emergence of National Aborigines Day}

In its first decade in New South Wales, NADOC was predominantly made up of non-Indigenous members; however, Indigenous people such as Charles Perkins attended some meetings and others such as Jimmy Little played a major role in organising events. ${ }^{12}$ In this article, we focus on the Indigenous activists and entertainers who participated in NADOC events, including Jim Hamilton, Joyce Mercy, Margaret Morris, Frank Roberts and Jack Simms who gave speeches; and Lorna Beulah, Harold Blair, Nancy Ellis, Col Hardy, Eva Mumbler and Candy Williams who sang. Their presence and participation enabled Indigenous people to pursue their own political and cultural agendas through the events organised by NADOC. Their involvement suggests that they shared the conviction, of earlier generations of Indigenous activists, that collaboration with non-Aboriginal people was vital in influencing public opinion. ${ }^{13}$ High-profile activist and poet Kath Walker (Oodgeroo Noonuccal), who participated in National Aborigines Day in Sydney in 1965, wrote about the 'organisational role' that white Australians could play 'in assisting the Black Australian to reach his own type of achievement with his own set of values'. ${ }^{14}$

The events of National Aborigines Day can be identified as part of the history of Indigenous activism. National Aborigines Day has a direct link with the Melbourne-based Australian Aborigines' League, founded by William Cooper in 1932, and the Aborigines Progressive Association, an all-Aboriginal organisation founded in New South Wales by Jack Patten and William Ferguson in 1937. Cooper and Ferguson initiated the Aboriginal Day of Mourning, first held in Sydney on 26 January 1938, building on Cooper's work with the league, which included presenting an Aboriginal choir in concert for Melbourne's anniversary celebrations in $1937 . .^{15}$ By 1940 , Cooper had engaged the National Missionary Council of Australia to dedicate the Sunday prior to Australia Day to observing the Day of Mourning in church services. This is recognised as one of the originating impulses for National Aborigines Day. ${ }^{16}$

12 SLNSW, MLMSS 4265.

13 Taffe 2005: 22.

14 However, Walker was very specific about the nature of 'coalitions' between Black and white Australians and the anti-racist self-education that was necessary for whites to undertake in order to form 'effective alliances with Black Australians'; Kath Walker (Oodgeroo Noonuccal), 'Coalition of Black and White Australians', 1969, UQFL84, Box 30. (Authors have followed Kath Walker's style with capitalisation of Black in this article.)

15 Attwood 2003: 69-74.

16 Aboriginal and Torres Strait Islander Commission 2003. 
In the records of NADOC's first decade, the Sunday of observance for Aborigines is recounted as a joint undertaking of the Australian Board of Missions and the Church Missionary Society. ${ }^{17}$ These were organisations of the Anglican Church, active since the mid-1800s in missionary endeavours engaging the Indigenous people of Australia. Under the auspice of the National Missionary Council of Australia (NMCA), they promoted Aboriginal Sunday from 25 January 1952, with the hope that 'the Church may influence and inspire [non-Indigenous] people everywhere to a new attitude to these kindly people, the original inhabitants of our land'. ${ }^{18}$ By 1956, the NMCA was seeking to broaden the reach beyond observance in church. As chairman at the inaugural meeting of NADOC, Rev. V.W. Coombes outlined the plans for 'a National Aborigines Day which was not confined to the Sunday - which reached only a section of the community - but which could bring in the newspapers, broadcasting and governmental activities'; the aim was to 'bring about a change of heart on the part of the [white] people and develop a new form of public opinion' with the 'obligation ... not only to work on reconditioning the Aborigine, but on reconditioning the white man to receive the Aborigine. ${ }^{19}$

In their visions of futurity and endeavours to effect social change during this period, Indigenous and non-Indigenous people were often at cross-purposes. The 'reconditioning [of] the white man' was an objective strongly supported by Aboriginal people, but for them this reconditioning was not just for the purpose of 'receiv[ing] the Aborigine' into the mainstream but for 'the white man' to get his own house in order: ${ }^{20}$ to address the ongoing brutalising effects of colonisation on white people themselves and the culture of cruelty and aggression that was the legacy of colonisation. Kath Walker (Oodgeroo), who participated in many political fora and cultural events of the period and was prominent in a wide range of mainstream news and entertainment media, insisted that Aboriginal economic advancement was dependent not only upon the transformation of Aboriginal people and culture but on that of white people and culture. She wrote:

Let the white man reconstruct his own race and let the black man reconstruct his race. When all races have achieved that aim, then and only then can black and white come together as friends and neighbours. ${ }^{21}$

17 NADOC records at the State Library of NSW are included in collections from Rev. A.W. Grant (MLMSS 4265), the Australian Board of Missions (MLMSS 4503) and the Aboriginal-Australian Fellowship (MLMSS 4057).

18 Appeal to the Clergy of Australia: Aboriginal Sunday, 25 January 1952, SLNSW, MLMSS 4503.

19 Minutes, Inaugural Meeting of the Aborigines Day Observance Committee, Sydney, 27 July 1956, SLNSW, MLMSS 4503; Rev. V.W. Coombes represented the Australian Presbyterian Board of Missions.

20 Minutes, Inaugural Meeting of the Aborigines Day Observance Committee, Sydney, 27 July 1956, SLNSW, MLMSS 4503.

21 Kath Walker (Oodgeroo Noonuccal), 'Black Australians', speech delivered to the Journalists Club, 16 August 1969, UQFL84, Box 30, p. 4. 
If the non-Indigenous participants in the planning of National Aborigines Day were targeting white audiences with the aim of facilitating assimilation, many Aboriginal commentators at this time envisaged that future interracial relations would be based on a radical change or reconfiguration of whiteness on a scale that was not acknowledged in non-Indigenous formulations of assimilation. Whiteness required, in Walker's words, wholesale 'reconstruction'.

The decade between the first NADOC events of 1957 and the 1967 referendum saw a concerted effort on the parts of both Indigenous and non-Indigenous people to court the media. Publicising National Aborigines Day was a priority for NADOC. While Aboriginal Sunday had been largely a religious observance, a 'day of penitence', 'prayer and intercession' and 'consecration to the task', National Aborigines Day became an exercise in public relations. ${ }^{22}$ From the outset, NADOC sought to change public opinion through a nationally coordinated program engaging media organisations, commercial enterprise and service organisations. In each state, they sought newspaper coverage and radio programming; in Sydney, they sought publicity on $\mathrm{ABC}$ television, then in its first year of broadcasting. They approached major department stores to display exhibitions of Aboriginal art and mission handicrafts for sale, and they cooperated with Rotary, Apex and the Country Women's Association to access distribution channels beyond churches and schools. ${ }^{23}$

In its first decade, NADOC was committed to promulgating assimilation. It framed the purpose of National Aborigines Day in alignment with federal government policy. This purpose included 'an acknowledged acceptance of assimilation within the Australian community as the objective, and towards this end the earliest possible complete acceptance of Aborigines by the white community at all stages and standards of their living. ${ }^{24}$ The federal government provided materials to promote National Aborigines Day. From 1957, the Department of Territories produced booklets annually, largely written from an anthropological point of view, which sought to educate nonIndigenous audiences about Australian Indigenous peoples. Paul Hasluck, Federal Minister for Territories, funded the printing of 80,000 copies of Our Aborigines (1957) for distribution by NADOC in 1957.25 The government funded similar print runs each year. According to Russell McGregor, these booklets were 'the federal government's first foray into propaganda intended to sway mass opinion towards a more favourable view of Aboriginal people and greater involvement in Aboriginal affairs'. ${ }^{26}$

The first National Aborigines Day organised by NADOC was held on Friday 12 July 1957, with church services on the following Sunday. The committee's report on activities lists $\mathrm{ABC}$ television and radio coverage, including members of

22 Appeal to the Clergy of Australia: Aboriginal Sunday, 25 January 1952, SLNSW, MLMSS 4503.

23 Minutes, NADOC, Sydney, 29 August 1956-23 July 1957, SLNSW, MLMSS 4503.

24 Minutes, NADOC, Sydney, 8 March 1957, SLNSW, MLMSS 4503.

25 NAA, A452, 1957/2671.

26 McGregor 2011: 89. 
the committee, the Singleton Aborigine Choir and an Aboriginal concert in Bega, as well as the Children's Session on radio $2 \mathrm{CH}$, the station owned by the NSW Council of Churches. There were window displays at the Anthony Hordern \& Sons department store and the County Council Electricity Department in Sydney, and at the British and Foreign Bible Society Centre in Canberra. In Brisbane, the Lord Mayor opened a display at City Hall and Hasluck attended a dinner; in Adelaide, a concert by Aboriginal artists was given in the Masonic Hall; and in Melbourne, Hasluck was guest speaker on Sunday at the Wesley Methodist Church. Overall, Hasluck was impressed by the media coverage achieved nationally, commenting to Rev. Coombes that the 'Committee had accomplished in two days something the Government had not been able to accomplish over many years'. ${ }^{27}$

The report on NADOC's second National Aborigines Day, held on Friday 11 July 1958 , records 'a much wider and [more] powerful observance than that of $1957^{\prime} .^{28}$ A similar range of activities was generated in the state capitals - public meetings and church services, window displays in department stores, coverage in the press, radio broadcasts and, in Sydney and Melbourne, television broadcasts. Seventy thousand pouches containing 12 photographs, probably those reproduced in the booklet Assimilation of Our Aborigines (1958), were distributed through schools, universities, service organisations and trade unions, along with 10,000 posters for display. A short film from the Department of Territories, titled End of the Walkabout, was nationally distributed in multiple copies for public exhibition and broadcast on ABC television in Sydney and Melbourne. ${ }^{29}$ Further films were distributed for National Aborigines Day in subsequent years.

For the third National Aborigines Day, held on 10 July 1959, the NSW committee staged a demonstration in Martin Place, the civic heart of Sydney, site of the General Post Office and the Cenotaph memorial. The term 'demonstration' requires clarification, since the event was not a protest march with banners, chants and slogans. Rather, it was a civic ceremony, with dignitaries in attendance and an orderly program of speeches, presentations and addresses, interspersed with musical performances and physical displays. Many speakers were non-Indigenous, but Indigenous speakers and performers played an important role in the proceedings. The non-Indigenous dignitaries included Governor of New South Wales Lieutenant General Sir Eric Woodward and Paul Hasluck. The event attracted an audience of more than 2,000 people. The Indigenous speaker was Jack Simms of La Perouse, vice president of the AAF, who 'appealed for full citizenship rights for aborigines' in his address. ${ }^{30}$ Aboriginal children from the La Perouse Public School performed a 'folk

\footnotetext{
27 Minutes, NADOC, Sydney, 23 July 1957, SLNSW MLMSS 4503.

28 Report of National Aborigines Day and Aborigines Sunday, 11-13 July 1958, SLNSW, MLMSS 4503.

29 NFSA 21836; 'TV and radio', Sun-Herald, 13 July 1958: 94; 'Sunday television', The Age, 11 July 1958 : Radio/TV Supplement 8.

30 The AAF 'ensured that black people would speak' at the NADOC demonstrations; in addition to Simms, these speakers included Herbert Groves, Charles Leon, Joyce Mercy, Jack Hassen and Clive Williams (Horner 1983: 171).
} 
dance' that would appear to be of British or European origin, given the costuming and choreography captured by a photographer for the Sydney Morning Herald. ${ }^{31}$ In this regard, the 1959 demonstration succeeded in attracting press coverage and public interest.

From 1960 to 1965, National Aborigines Day in Sydney was observed annually as a demonstration in Martin Place. The dignitaries on these occasions included white men of government, church, academia and the media, and representatives of the organising committee (Figure 1). ${ }^{32}$ Their civic status lent significance to the occasions, attracting public notice in the press and attention from white Australians. The programs suggest that the participation of Aboriginal people was framed by items that asserted the priority of non-Aboriginal Australians and the state. At the 1960 demonstration, the address by Pastor Frank Roberts, musical items from Jimmy Little and Candy Williams, and performances by the children of La Perouse Public School were prefaced by the playing of the national anthem ('God Save the Queen') and an opening speech from the Lord Mayor, who also provided 'concluding remarks' before the police band played 'Advance Australia Fair'. ${ }^{33}$ Yet there are also some indications that the demonstrations did not run strictly according to the programs. There were aspects of improvisation, and some details, such as the topic of speeches and the selection of songs, that were not specified in advance.

In focusing on the participation of Aboriginal people in National Aborigines Day, we emphasise the agency they exercised in choosing to participate, in selecting their repertoire and contributing their voices, talents and energies to the events. In the remainder of this article, we investigate how various Aboriginal people, who participated in National Aborigines Day in Sydney between 1957 and 1967, used the arts to express Aboriginal cultural and political imperatives. Our analysis identifies two ways in which Aboriginal people participated: as activists addressing the audience in speech and as singers and musicians providing entertainment. Some of these people like Charles Perkins and Jimmy Little were profiled as 'successful Aborigines' in One People, one of the government-produced booklets, distributed by NADOC in $1961 .^{34}$ But their participation in National Aborigines Day entailed an exercise of agency - writing speeches, selecting repertoire, delivering performance, engaging an audience - which extends beyond their portrayal as models of assimilation in a government publication. We conclude by considering the significance of NADOC's first decade of achievement in the public sphere.

31 'Folk dancing to mark Aborigines' Day', Sydney Morning Herald (hereafter SMH), 11 July 1959: 1; 'Native rights appeal', $S M H$, 11 July 1959: 4.

32 In addition to Woodward and Hasluck, regular dignitaries included Harry Jensen, Lord Mayor of Sydney; C.A. Kelly, NSW Chief Secretary; Rev. A.W. Grant, NADOC chairman; Professor William Geddes, University of Sydney; Martin Royal, ABC announcer; and representatives of the Rural Bank.

33 'Aborigines remembered: Ceremony in Sydney', Dawn, July 1960: 1.

34 Department of Territories 1961a: 26-32. 


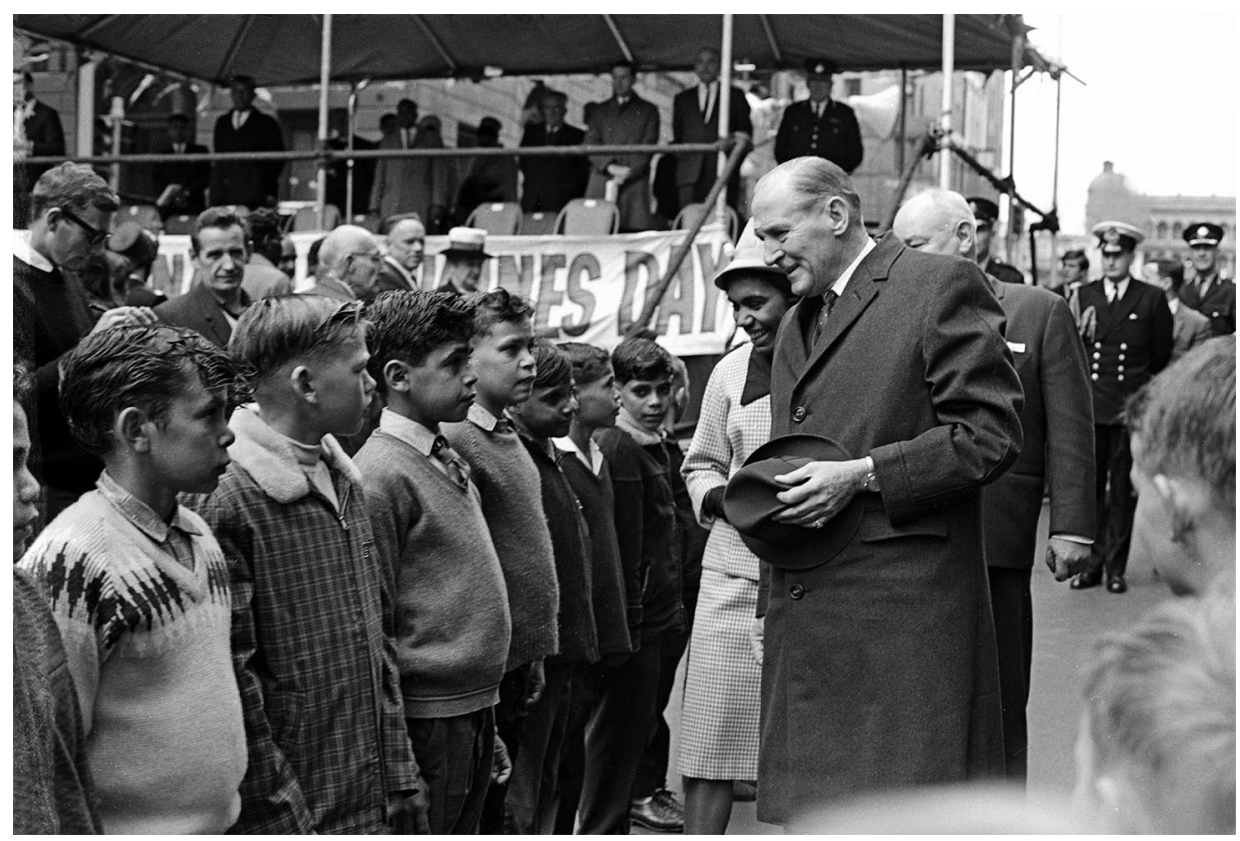

Figure 1: Sir Eric Woodward, the Governor of New South Wales, accompanied by Joyce Mercy, meeting students at the National Aborigines Day demonstration in Martin Place, Sydney, 9 July 1965.

Source: R.L. Stewart, Fairfax, FXB246664.

\section{Indigenous self-representation: Activists addressing audiences in speech}

Aboriginal activists used the occasions created by NADOC in Sydney to articulate their own political goals and social agendas. From 1959, NADOC provided a platform for Aboriginal figures of national prominence to deliver powerful speeches that described the mistreatment of Aboriginal people, in particular those living in rural and remote regions, about whom many white Australians living in the capital cities would have had little knowledge. Joyce Clague (née Mercy), who spoke at the National Aborigines Day in Sydney in 1964, describes white audiences at this time being 'shocked [at] the conditions we had grown up with'. ${ }^{35}$ The speeches addressed the politics of citizenship and racial discrimination, setting Australia's mistreatment of Aboriginal people within the international context of the United Nations and

35 Joyce Clague, as quoted in Pauline Clague's personal communication with Anne Brewster and Jonathan Bollen, 3 November 2017. In addition to her participation in NADOC events, Joyce Mercy (as she was then known) was associated with the Aboriginal-Australian Fellowship and involved in establishing the Foundation for Aboriginal Affairs in 1964; see Taffe 2014. 
the Universal Declaration of Human Rights. When Jack Simms 'appealed for full citizenship rights for aborigines' in addressing 'more than 2,000 people' at the 1959 National Aborigines Day in Martin Place, he explained:

I don't mean citizens' rights to go into the pub and drink beer. We want to be given citizenship, and we shall keep on fighting for it. We want to be decent citizens like anyone else. I think we are the only people in Australia who have not got citizens' rights. ${ }^{36}$

Simms drew attention to racial segregation, with 'special roped-off seats in country theatres' where 'aborigines had to sit', and told reporters that 'segregation in NSW is "just as bad as in the United States"' ${ }^{37}$ At the Martin Place demonstration in 1960, Pastor Frank Roberts, the activist-evangelist who had participated in the 1938 Day of Mourning, proclaimed that ' $\mathrm{r}$ ] $\mathrm{acialism}$ was brutal and should never become implanted in the Australian way of life or thought'. In addressing the 'crowd of nearly 3,000', Roberts appealed to the 'spiritual and moral qualities' of white Australians 'to bring about assimilation': 'All of us want to see in our lifetime the elimination of racial torment and racial bigotry' and 'the eradication of racialism, which is felt in many parts of the world today'.$^{38}$

While speakers such as Jack Simms and Frank Roberts drew direct comparisons between Australia and the United States, Australian governments distinguished the policy of assimilation from apartheid in South Africa and segregation in the US. This distinction is expressed in Dawn's report on National Aborigines Day in 1960:

With the policy of assimilation adopted by Commonwealth and State Governments strongly supported by all churches and by individuals who will not tolerate the possibility of apartheid in this country, the aborigines are called upon to adjust themselves to a new way of life in our democracy. ${ }^{39}$

From this perspective, the interpellation of assimilation ('called upon to adjust themselves') was justified by extending the promise of national belonging: 'Because they are people of skill and inherent vision we Australians have confidence in their ability to take the responsibilities of full citizenship. ${ }^{40}$ Yet when invited to address the experience of assimilation, Aboriginal speakers took the opportunity to articulate their own vision of national belonging, one that affirmed their autonomy, heritage and difference.

36 'Native rights appeal', SMH, 11 July 1959: 4; Jack Simms, from the Aboriginal community at La Perouse, was federal vice-president of the Aboriginal-Australian Fellowship.

37 'Animals! Aborigines' plight', Daily Mirror, 10 July 1959: 1.

38 'Racialism "brutal": Aboriginal asks for toleration', Dawn, July 1960: 1.

39 'Aborigines remembered: Ceremony in Sydney', Dawn, July 1960: 1; see also, 'Advances in treatment of Aborigines', SMH, 14 July 1958: 2.

40 Dawn, July 1960: 1. 
Aboriginal speakers also used the occasions presented by National Aborigines Day to convene an Aboriginal audience. We see evidence of this in a speech delivered by Margaret Morris at National Aborigines Day in $1961 .{ }^{41}$ She was invited to speak 'on behalf of the aboriginal women of New South Wales', ${ }^{42}$ her 'stirring address' was later printed in Dawn under the headline, 'We are a proud people'. ${ }^{43}$ Although Morris endorses assimilation, she does so cautiously and somewhat reluctantly, attesting to the complexity and 'nebulous' quality of the term. ${ }^{44}$ She specifically stipulates that she supports the role of assimilation in bringing about the economic incorporation of Aboriginal people into the mainstream. She talks about making the decision to move her family into 'the white community' for the sake of her children's upward mobility. However, she resists the agenda of some proponents of assimilation to facilitate the cultural and biological absorption of Aboriginal people. She insists that her family's incorporation into the mainstream should not imply that her children must give up their Aboriginality. Her speech has a dual purpose: while addressing her white audience in order to demand economic parity, she also takes the opportunity to address and galvanise Aboriginal people. Morris affirms Aboriginal difference, declaring that Aboriginal people are a 'proud people', and exhorts them to wear their Aboriginal heritage 'like a badge'. In the last two paragraphs of her speech, she slips into the second-person, addressing her Aboriginal audience directly, saying, 'you, the Australian aborigines, are the only true Australians'. Here is an instance of Aboriginal activists taking advantage of National Aborigines Day to reach out to Indigenous audiences, to affirm Indigenous networks and solidarity. In doing so, they demonstrated their autonomy in ways that contested, subverted and exceeded the non-Indigenous organisers' vision of National Aborigines Day, which prioritised Aboriginal people's cultural assimilation into the mainstream and non-Indigenous Australians' 'acceptance' of them.

Despite the prospects of interracial address at the demonstrations in Martin Place, the political agendas of Aboriginal activists speaking at National Aborigines Day were not accurately represented in the press. In 1961, a reporter for the Daily Mirror transformed Margaret Morris's claim that 'We believe we should be entitled to "a place in the sun"; a position of equality - no more' into 'We ask for assimilation so we may live as human beings should - no more. ${ }^{45}$ Likewise, the Sydney Morning Herald misquoted Joyce Mercy's speech for National Aborigines Day in 1964 (Figure 2). The reporter transformed Mercy's call for 'special efforts to ensure that Aborigines have equal opportunities in the future' into 'a special effort towards

41 'Mrs Margaret Morris, President of the Burnt Bridge-Greenhill Country Women's Association, addresses the National Aborigines' Day ceremony in Martin Place, Sydney', Dawn, July 1961: 2.

42 'To-day I feel very honoured', anon. typescript, undated, SLNSW, MLMSS 4265.

43 Margaret Morris, 'We are a proud people! A stirring address', Dawn, October 1961: 1-2.

44 See, for example, the discussion of assimilation in Kerin 2005.

45 'Must break color', Daily Mirror, 14 July 1961: 9. 
a better deal for aborigines in the future', even though the phrase 'better deal' does not appear in Mercy's published speech. ${ }^{46}$ The political language of advocacy and demand - the calls made by Morris and Mercy for equality and equal opportunity - are transformed into ameliorative statements about a 'better deal' and the putative benevolence of assimilation.

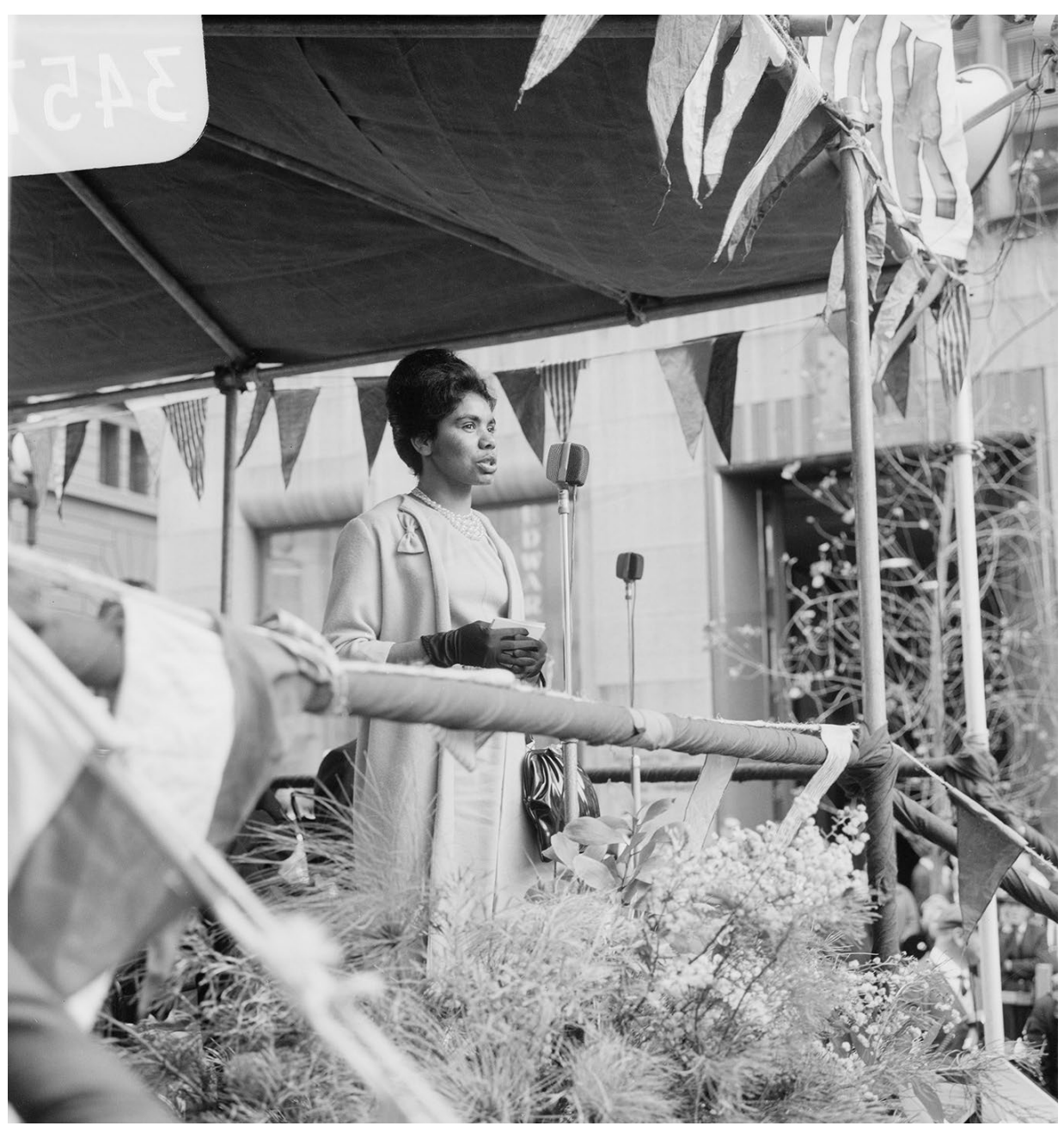

Figure 2: Joyce Mercy speaking at the National Aborigines Day demonstration in Martin Place, Sydney, 10 July 1964.

Source: State Library of New South Wales, Government Printing Office 2-34571.

46 'Aboriginal makes plea for "better deal” at Sydney ceremony', SMH, 11 July 1964: 4; 'Colourful ceremony in Martin Place', Dawn, July 1964: 1-3. 
By 1965, the opportunity that National Aborigines Day provided to Indigenous activists and performers to address non-Indigenous Australians in political discourse, to challenge the government policy of assimilation and to drive the agenda for administrative reform, becomes more evident in press reports. This can be illustrated through the involvement of Charles Perkins in National Aborigines Day events. In the early 1960s, Perkins was a professional soccer player and student at the University of Sydney. He participated in National Aborigines Day in 1962, joining the singers Jimmy Little, Col Hardy and Candy Williams for photographs at the exhibition of Aboriginal art held at the Wales Gallery in Sydney (Figure 3). ${ }^{47}$ In 1964, Perkins took an official role, welcoming the guests and the public to the demonstration in Martin Place, and escorting the Lieutenant Governor of New South Wales, Sir Kenneth Street, on an inspection of a guard of honour composed of school boys from Nowra and their hosts from Collaroy Plateau. ${ }^{48}$ At National Aborigines Day in 1965, having drawn high-profile attention to racism in regional New South Wales on the Freedom Ride with university students, Perkins was the leading Indigenous male speaker at the demonstration in Martin Place. ${ }^{49}$ In his address, Perkins responded to the speeches given by two white politicians: A.D. Bridges, the NSW Minister for Child Welfare, who announced that the recently elected Liberal Government would 'appoint a select committee to inquire into all aspects of Aborigines' conditions'; and Mrs Edna Roper, the Labor Member of the NSW Legislative Council, newly in opposition. ${ }^{50}$ Dawn records that, in welcoming the government inquiry, Perkins said that 'Aborigines must be consulted about their present position and about the future' and that 'there should be more Aborigines on the Aborigines Welfare Board'. ${ }^{51}$ The Sydney Morning Herald reports that Perkins 'told the gathering in Martin Place that assimilation of Aborigines would be achieved much sooner if more Aborigines were given a voice in their future' and quotes him saying, 'Aborigines are not advancing with the nation's growth' and ' $\mathrm{t}$ ] he aboriginal person must be consulted about his future and present situation'. ${ }^{52}$

The other Aboriginal people speaking at National Aborigines Day in 1965 were Joyce Mercy who gave the welcome, Jim Hamilton from the One People of Australia League (OPAL) in Queensland, and Kath Walker (Oodgeroo) who was invited to speak 'on behalf of Aboriginal women'. ${ }^{53}$ As part of her address, Walker read from We Are Going, her first collection of poems (Figure 4). ${ }^{54}$ While neither Dawn

\footnotetext{
47 Dawn, August 1962: 1. The Wales Gallery was in the Old Herald Building, on the corner of Pitt and Bridge Streets.

48 Dawn, July 1964: 1-2.

49 Perkins 1965.

50 'NADOC ceremony speaker tells of select committee', Dawn, July 1965: 1.

51 Dawn, July 1965: 2.

52 SMH, 10 July 1965: 6.

53 'Programme. National Aborigines Day Demonstration. Martin Place, Sydney, 9 July 1965', SLNSW, MLMSS 4057; ABC, TARA 350848.

54 Walker 1964.
} 
nor the Sydney Morning Herald report the title of the poem that Walker read, the Herald quotes Walker as saying, 'Australia is our country - let us shape its future together, not apart', and records that she 'recited one of her poems, calling for equality, fellowship, and independence for aborigines'. ${ }^{55}$ The poem that Walker read is the 'Aboriginal Charter of Rights', which includes the lines, 'Make us equals, not dependents', 'We want freedom, not frustration', 'Independence, not compliance', 'Give us fellowship, not favours' ${ }^{56}$ In reading the 'Charter' from the dais, Walker reached beyond her allocated brief. Tasked by NADOC to deliver a 'short address' 'on behalf of Aboriginal women', Walker took advantage of the occasion to advocate for political change and policy reform in the international language of human rights and self-determination. ${ }^{57}$

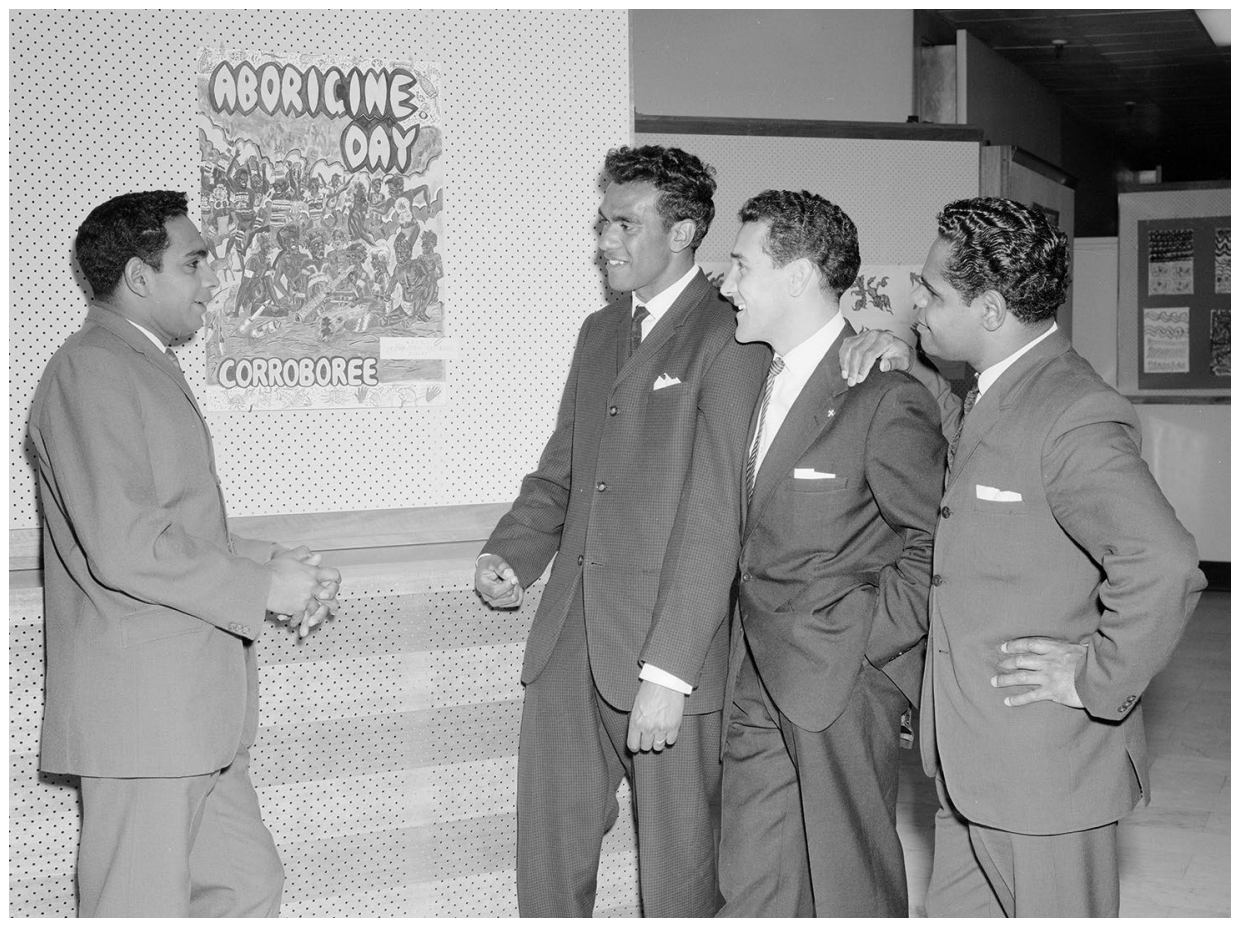

Figure 3: Jimmy Little (left) with Col Hardy, Charles Perkins and Candy Williams at the art exhibition for National Aborigines Day, Sydney, 13 July 1962.

Source: State Library of New South Wales, Government Printing Office 2-20003.

55 'A lunch-hour crowd of several hundred watched the ceremony to mark National Aborigines' Day held in Martin Place yesterday', $S M H, 10$ July 1965: 6.

56 'Aboriginal Charter of Rights', Walker 1964: 9-10; the catalogue record for ABC, TARA 350848, includes the short description, 'Walker reads Charter'.

57 'Programme. National Aborigines Day Demonstration. Martin Place, Sydney, 9 July 1956', SLNSW, MLMSS 4057. 


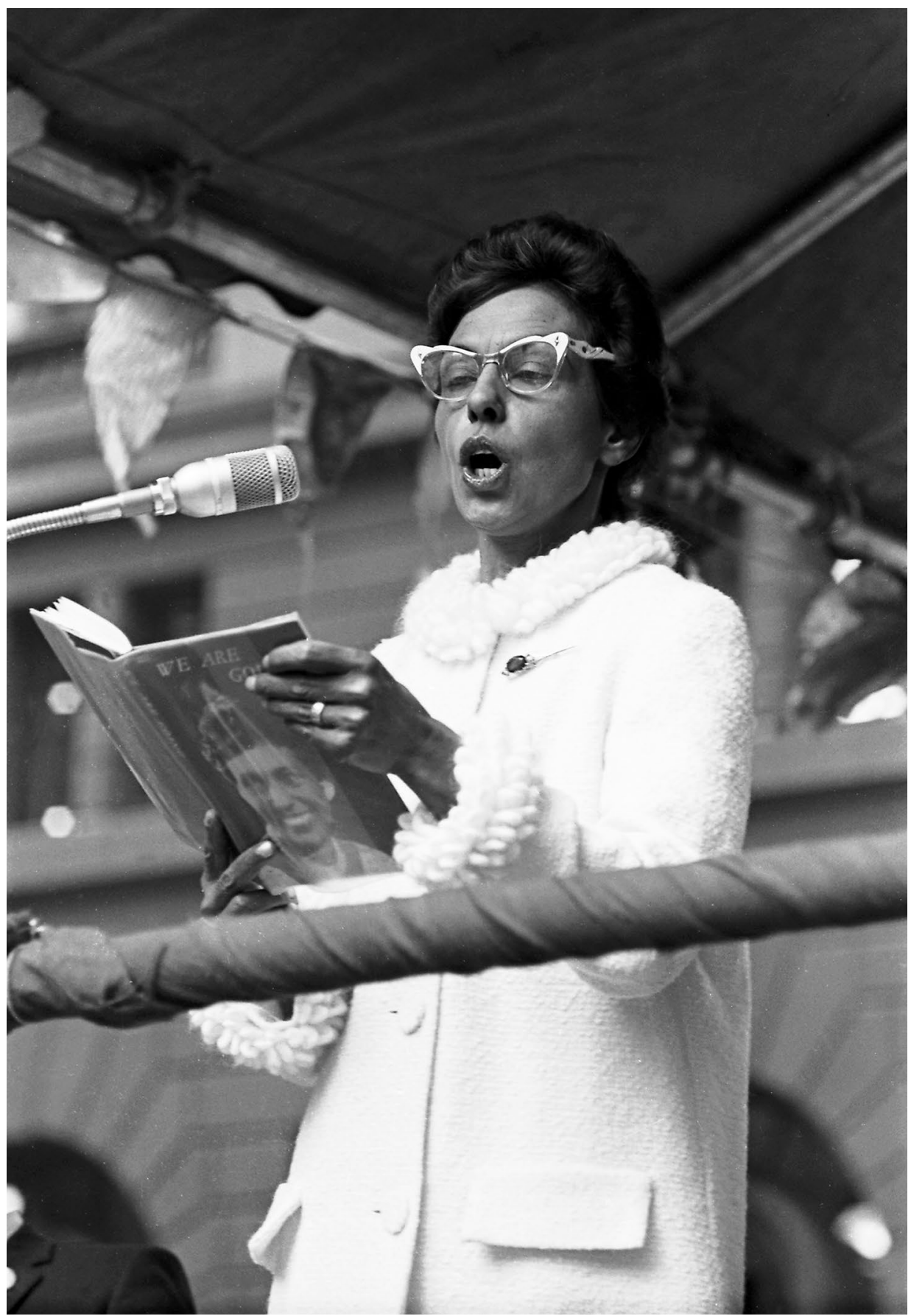

Figure 4: Kath Walker (Oodgeroo Noonuccal) reading from her book of poetry, We Are Going, at the National Aborigines Day demonstration, Martin Place, Sydney, 9 July 1965.

Source: R.L. Stewart, Fairfax, FXJ363191. 
The political rhetoric of Walker's poetry was reinforced on that occasion in music performed by a white Australian folk singer. Dawn reports that Gary Shearston sang a song by Dougie Young of Wilcannia, probably 'The Land Where the Crow Flies Backwards', and his own setting of one of Walker's poems, almost certainly 'We Are Going'. ${ }^{58}$ In fact, Shearston only borrows the title of Walker's poem, adding 'to Freedom' to transform its meaning for a call-and-response protest song, which he modelled on 'We Shall Overcome', the anthem of the American civil rights movement. Shearston based the melody on a chant taught to him by Roy Dadaynga, a Yirrkala man who stayed on in Sydney after touring with the Australian Elizabethan Theatre Trust in $1963 .{ }^{59}$ We now turn to the singers and musicians who performed at National Aborigines Day events in Sydney.

\section{Indigenous self-representation: Singers and musicians providing entertainment}

From the outset, NADOC called on Aboriginal singers and musicians to provide entertainment for National Aborigines Day in Sydney. At the demonstrations in Martin Place, musical items were interposed between the speeches, filling out the program and building a sense of occasion. Singers like Harold Blair, Jimmy Little, Lorna Beulah and others demonstrated musical talents across a broad repertoire including opera, lieder, gospel, country, pop, Indigenous songs and syncretic forms. They popularised Aboriginal people as celebrity-citizens, modelling class mobility and apparently successful assimilation within modern Australia. An observation from Jack Horner, the Secretary of the AAF, describes this dynamic as a movement beyond the paradigm of tradition. He observed the crowd in Martin Place in 1961 being 'taken by surprise at the "popular" style of singing', as if they had been 'vaguely expecting Aboriginal music of some sort'. He recognised the surprise as having 'taught the people in Martin Place that you should expect modern values from NSW Aborigines'. ${ }^{60}$ The surprise Horner observes can be seen as an index of white attitudes being 'reconstructed' (as Kath Walker put it), a process brokered by the self-representation of Aboriginal modernity.

Nancy Ellis sang at a public meeting for National Aborigines Day in 1958. The title of the meeting was 'End Australia's Apartheid'. Ellis had moved from Western Australia to study at the Sydney Conservatorium of Music in $1953 .{ }^{61}$ This suggests a classical repertoire of operatic arias and lieder, although it is not recorded what she sang at the meeting. The committee also approached Harold Blair, who by that time had established a public profile through radio, recording and concert tours. ${ }^{62}$

58 Dawn, July 1965: 2; Walker 2014: 93; NFSA 283503.

59 Andrews 1966; 'Festival of Aboriginal arts', Daily Mirror, 9 July 1965: 18; Casey 2011.

60 J. Horner to J. Rogalsky, 15 July 1961; J. Horner to L. H. Cocks, 15 July 1961; SLNSW, MLMSS 4057.

61 Fairfax, FXT310206.

62 Harrison 1975; Harold 1994. 
Blair would perform at the National Aborigines Day demonstration in 1963, but he was unable to accept the initial invitation to perform in 1958 due to a theatrical engagement in Melbourne. ${ }^{63}$ In the discourse of assimilation, Ellis and Blair provided models of 'successful Aborigines', which is how Blair was profiled in One People, the NADOC booklet for $1961 .^{64}$ They were admired for their success in arts and education, and for the way their singing from the classical repertoire appealed to a cultivated audience of white Australians. However, it is important to recognise that Ellis and Blair were also involved in activism. Ellis was active in the AAF, the organisation founded by Faith Bandler and Pearl Gibbs to 'promote better understanding between aborigines $[s i c]$ and European Australians' ${ }^{65}$ Blair was a member of the Aborigines' Welfare Board (1957-59) and became involved in the Aborigines Advancement League and the Federal Council for the Advancement of Aborigines and Torres Strait Islanders (FCAATSI). ${ }^{66}$

The involvement of Ellis and Blair in Aboriginal activism points towards another repertoire of songs. 'Negro spirituals', popularised in Australia through the minstrel tradition, acquired a political significance in postwar Australia, in part through the recordings of Paul Robeson, which circulated prior to his tour in $1960 .{ }^{67}$ Robeson's career as an African-American singer and political activist in the trade union and civil rights movements in the US was widely reported in Australia. In linking artistic achievement with the politics of civil rights, the figure of Robeson and his repertoire of music informed media reportage on Harold Blair. Newspaper reporters hailed Blair as the 'Australian Paul Robeson', in particular, when he sang 'operatic arias' for conference delegates at the Australian Council of Trade Unions in $1947 .{ }^{68}$ Blair had attended the Grace Church in Harlem, earning some money singing gospel songs in the choir ${ }^{69}$ and a report from the 1966 Easter conference of the FCAATSI records that he sang Negro spirituals, probably from the repertoire popularised by Robeson. ${ }^{70}$ Blair's recordings adhere to the repertoire of opera (Puccini, Mozart) and lieder (Schubert, Schumann), although in 1956 he made a record of Australian Aboriginal Songs. Some of these were collected by Dr Harold Lethbridge in the 1920s, having been written by Boss Davey from the Maranoa district in Queensland, and one was composed by Reverend Ronald Trudinger at the Ernabella mission in the South Australia, drawing on Pitjantjatjara chants. ${ }^{71}$ Blair recorded the songs

63 Harrison 1975: 196; Blair performed in Noel Coward's Nude with Violin at the Comedy Theatre, Melbourne, from 21 June 1958. AusStage, 'Nude with Violin', Event 129601, www.ausstage.edu.au/pages/event/129601 (accessed 23 August 2017).

64 Department of Territories 1961a: 27.

$65 S M H, 11$ July 1956: 12; quoted in Horner 2004: 20.

66 Duncan 1993.

67 Curthoys 2010. The concert presented in Melbourne by the Australian Aborigines' League in 1937 also included 'African American spirituals' (Attwood 2003: 73).

68 'Native sings to unionists', News (Adelaide), 5 September 1947: 5; 'Aboriginal tenor "spellbinds" ACTU',

Daily News (Perth), 5 September 1947: 10.

69 Harold 1994.

70 Andrews 1966.

71 Casey 2008. 
in Melbourne, singing in an African-American gospel style, accompanied by a jazz quartet; however, non-Indigenous critics struggled to hear the modernity of Blair's music, insisting on its 'authentic native rhythms and primitive harmonies' instead. ${ }^{72}$

Blair sang at the First National Aborigines Day Revue with an all-Aboriginal cast, at the Anzac Auditorium, Sydney, on 10-11 July 1963. He performed songs from the opera or lieder repertoire, designated 'solos (classical)' in the printed program, and songs from another repertoire simply designated 'solos'.$^{73}$ At the demonstration in Martin Place on 12 July, he delivered a spoken address and sang, although no indication of repertoire is given. While songs from the classical repertoire demonstrated Aboriginal achievement for the audience of white Australians, songs from the gospel repertoire were associated with the advocacy of civil rights. For National Aborigines Day in 1963, it is likely that, in addition to classical items, Blair also sang from his repertoire of Aboriginal, spiritual and gospel songs. Blair kept the Aboriginal songs in his repertoire for 15 years or more, from his concert at the New York Town Hall in 1951 to performances during the Melbourne Olympic Games in 1956 and an appearance on Melbourne television in $1966 .^{74}$

In the 1960s, the musical repertoire for National Aborigines Day in Sydney was most substantially shaped by Jimmy Little. Little was from Cummeragunja, near Echuca, Victoria, a significant community in the struggle for Aboriginal rights. ${ }^{75}$ Little was initially a 'hillbilly singer', singing songs recorded by Nashville stars, before broadening his repertoire to include “"evergreen” Irish songs' like 'Danny Boy' and 'country-gospel' like his biggest hit 'Royal Telephone'. ${ }^{76}$ By his own account, Little was a versatile singer: he could also croon the theme songs from Hollywood movies, emulate the smooth soul of Sam Cook, and mix rockabilly hits with 'Aussie bush ballads' ${ }^{77}$ His breakthrough record in 1959, Ballads with a Beat, includes the Paul Robeson standard 'Ol' Man River' and a similar song of toil, 'That Lucky Old Sun', popularised by Louis Armstrong and Sam Cooke. Little also performed his own material, including 'Give the Coloured Lad a Chance', a protest song written by his father and recorded in 1958.

Little was the most prominent performer at National Aborigines Day in Sydney, singing at the Martin Place demonstrations in 1960, 1962-64 and in the Sydney Town Hall in 1967 (Figure 5). He was also a catalyst for other Indigenous artists to participate. In 1961, his father, Jimmy Little Senior, a seasoned entertainer himself, performed a 'gum-leaf duet' when his son could not attend. ${ }^{78}$ Other

72 Bill Patey, 'On the record', The Argus, 20 October 1956: 19, quoted in Casey 2008: 54.

73 SLNSW, MLMSS 4265.

74 Casey 2008: 59; 'Jimmy Hannan huffs and puffs', The Age, 19 May 1966: TV Radio Guide 1.

75 Jimmy Little's Gentle Journey 2003; Walker 2014: 21.

76 Walker 2014: 22.

77 Walker 2014: 32.

78 'Mr A. McLeod and Mr. Jimmy Little senior, accompanied by Miss Margaret Williams, all of Nowra, play a gum-leaf duet during the National Aborigines' Day ceremonies in Martin Place, Sydney', Dawn, July 1961: 3. 
Indigenous artists who performed at National Aborigines Day include Candy Williams (1960, 1963), Margaret Williams (1961, 1963), Col Hardy (1961-64), Lorna Beulah (1962-65), Eva Mumbler (1962), Fred Little (1963), Doug Peters (1963) and Heather Pitt (1964). Candy Williams, originally from Cowra, had been pivotal to the development of an Aboriginal music scene in Redfern, which included Jimmy Little and, later, Colin Hardy. ${ }^{79}$ Williams and Hardy toured with Little and his brother Fred in 'Australia's First All Coloured Show' in 1962. A similar line-up of artists performed at the First National Aborigines Day Revue, which Little produced and compered for National Aborigines Day in 1963 (Figure 6) ${ }^{80}$ For NADOC, this was 'the first Concert run entirely by Aboriginal people' and Little handled all the arrangements. For the Aboriginal entertainers, it was an opportunity for celebrity promotion. They designed the 'special souvenir programme' to include 'space for autographs' rather than advertisements. ${ }^{81}$

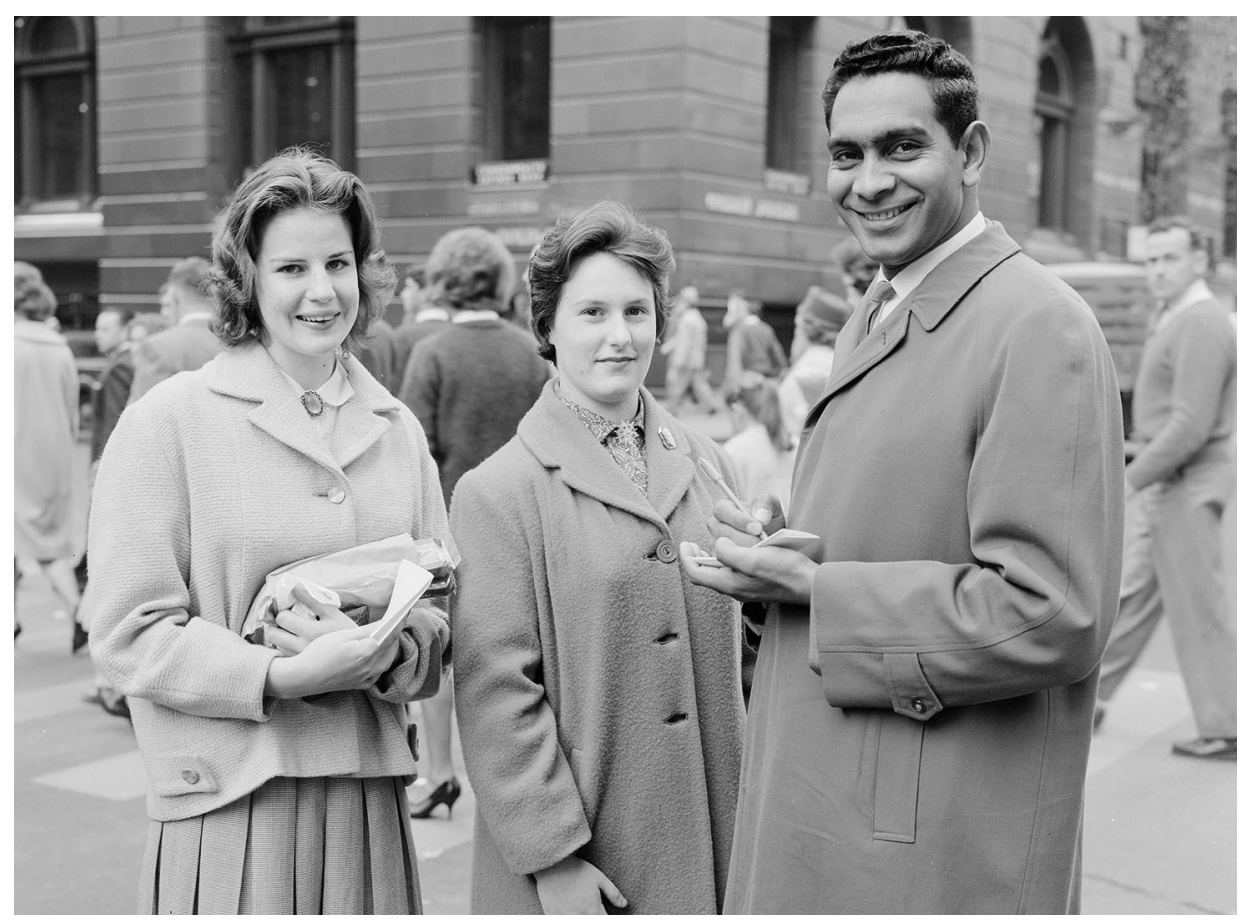

Figure 5: Jimmy Little signing autographs at the National Aborigines Day demonstration in Martin Place, Sydney, 13 July 1962.

Source: State Library of New South Wales, Government Printing Office 2-20007.

79 Walker 2014: 84-85.

80 Minutes, NSW NADOC meetings, 13 March 1963, 10 April 1963, SLNSW MLMSS 4265.

81 D. Graham to J. Horner, 8 May 1963, SLNSW, MLMSS 4057. 


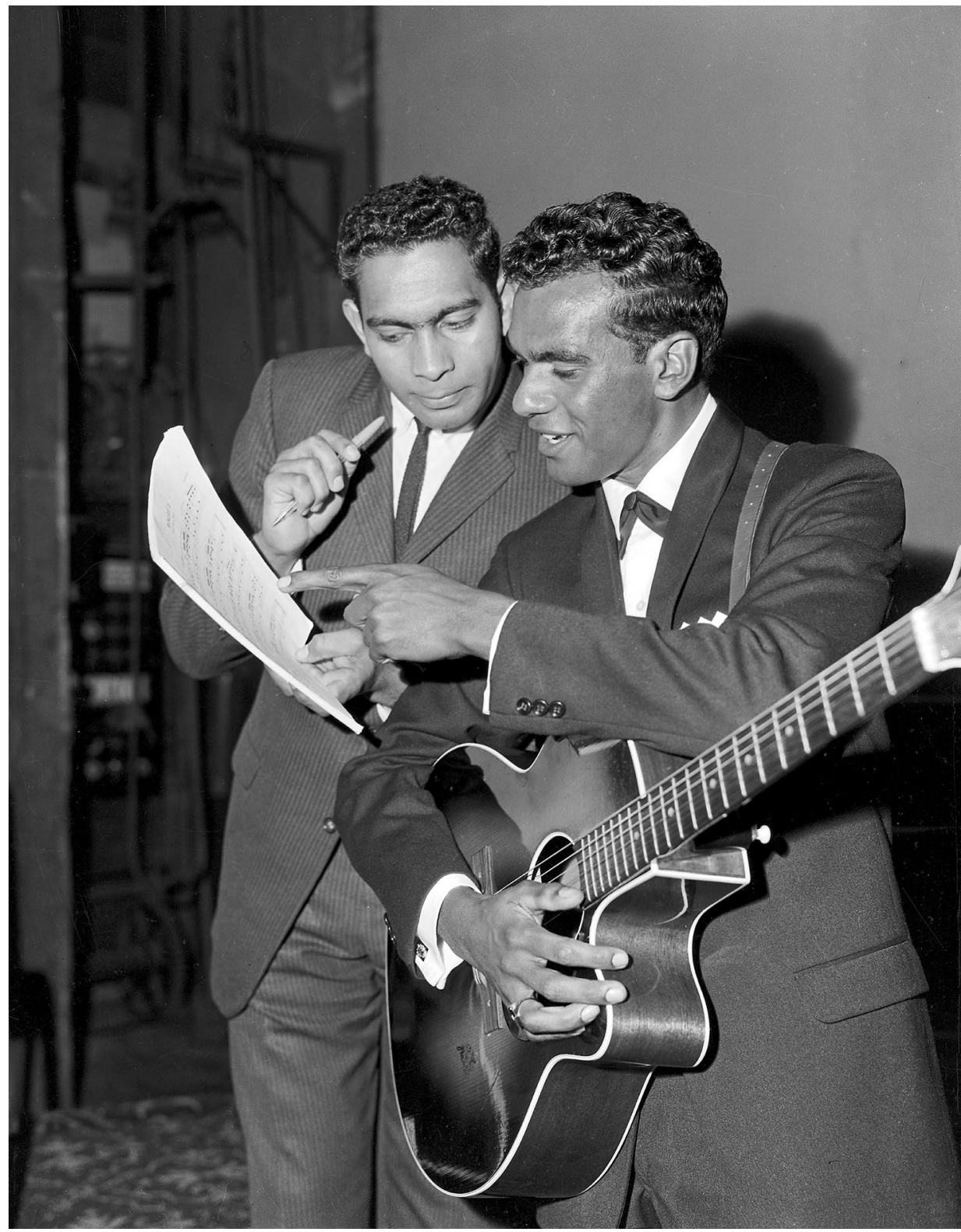

Figure 6: Jimmy Little and (probably) Candy Williams preparing for a concert for National Aborigines Day, at the Lyceum Theatre, Sydney, 14 July 1963. Source: SMH Picture by Ton Linsen, Fairfax, FXB247341. 
NADOC also adopted mechanisms to 'discover' Aboriginal talents beyond Sydney. These mechanisms indicate how NADOC conceived itself as an exercise in public relations with the capacity to create celebrities by bringing individuals to public notice. Colin Hardy, from Walgett, was a finalist in the first talent quest in 1961, judged by John Antill, the composer of Corroboree, the concert suite and ballet; the winner was Charles Edwards of Purfleet, near Taree, although the press did not follow his story beyond the event. ${ }^{82}$ The second talent quest for National Aborigines Day in 1962 produced two winners: Lorna Beulah and Eva Mumbler. Lorna Beulah, a Wiradjuri woman from Forbes, suited the narrative of discovery. Jack Horner of the Aboriginal-Australian Fellowship acknowledged NADOC's achievement in these terms: 'You have made a really good find in Lorna Beulah, and I hope that in the years to come you will find more rich talent of this quality' ${ }^{83}$ Dawn described Beulah as 'The Girl with the Golden Voice ... who stopped the Martin Place crowds in their tracks' with her 'mezzo-soprano voice of amazing range and beauty'. ${ }^{84}$ Beulah had studied at the Conservatorium of Music, Parramatta, in 1948, and presented a 'Celebrity Recital' at the Town Hall in Forbes in 1952. After marrying, she lived in Toongabbie in western Sydney, and later moved with her husband to Alice Springs. ${ }^{85}$ At Martin Place for National Aborigines Day in 1962, by then a mother of two, she sang from the classical and operatic repertoire: 'Songs My Mother Taught Me' by Antonín Dvořák, Mimi's song from La Boheme by Puccini and 'My Hero' from The Chocolate Soldier by Oscar Strauss (Figure 7). Like Nancy Ellis, she was hailed as an Australian Marian Anderson. ${ }^{86}$ She won a scholarship to the New South Wales Conservatorium of Music, sang on television in Bobby Limb's Sound of Music and toured nationally in Porgy and Bess.

By contrast, Eva Mumbler sang 'Old Rugged Hills of Home' (Figure 8), one of four songs composed by Grace O'Clerkin, which Mumbler had recorded as the duo Olive and Eva in 1955. Olive McGuinness and Eva Bell (later Mumbler) were associates of Candy Williams and performers in Redfern. According to Clinton Walker, the songs they recorded - 'Old Rugged Hills' with 'Rhythm of the Corroboree' and 'When My Homeland is Calling' with 'Maranoa Moon' - 'became Aboriginal standards, sung by everybody from Harold Blair to Jimmy Little' ${ }^{87}$ On winning the NADOC talent quest, however, Mumbler was not feted with a scholarship and forward bookings like Beulah. As a resident of Sydney, Mumbler's proximity may have worked against the narrative of 'discovery'. Her choice of repertoire, with its appeal to Aboriginal country and tradition, may have played a part.

82 'National Aborigines' Day ceremony in Sydney', Dawn, July 1961: 4; see also 'Purfleet', Dawn, September 1958: 10 .

83 J. Horner to J. Rogalsky, 14 August 1962, SLNSW, MLMSS 4057.

84 'Nightingale sang in Martin Place', Dawn, August 1962: 3.

85 'Personality - Lorna Beaulah (Mrs Tom Oliphant)', Irabina 1(7): 4, NLA MS 3677.

86 'Exhibition of Aboriginal art at new civic centre', Biz, 25 July 1962: 3.

87 Walker 2014: 84. 


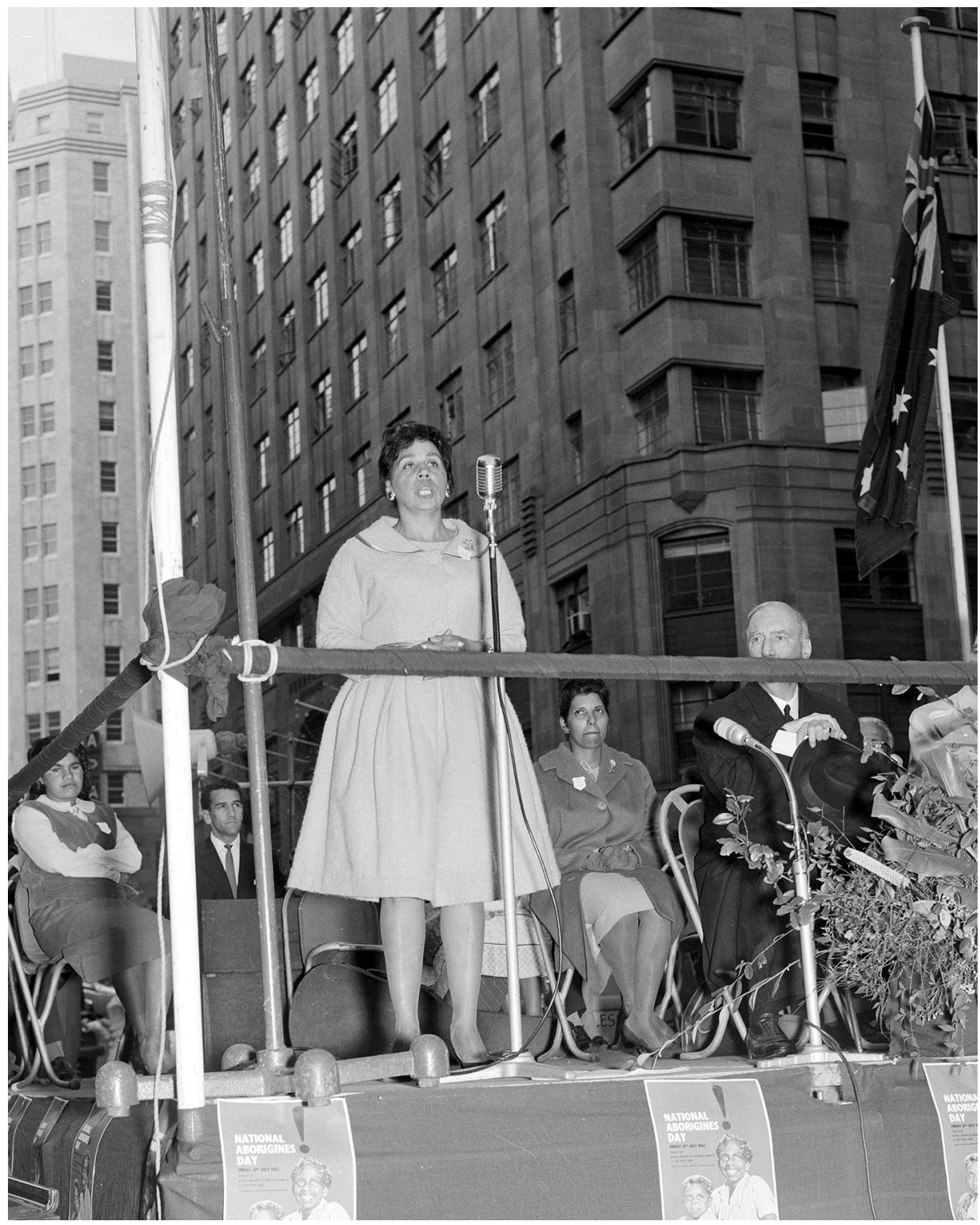

Figure 7: Lorna Beulah singing at the National Aborigines Day demonstration in Martin Place, Sydney, 13 July 1962.

Source: State Library of New South Wales, Government Printing Office 2-19997. 


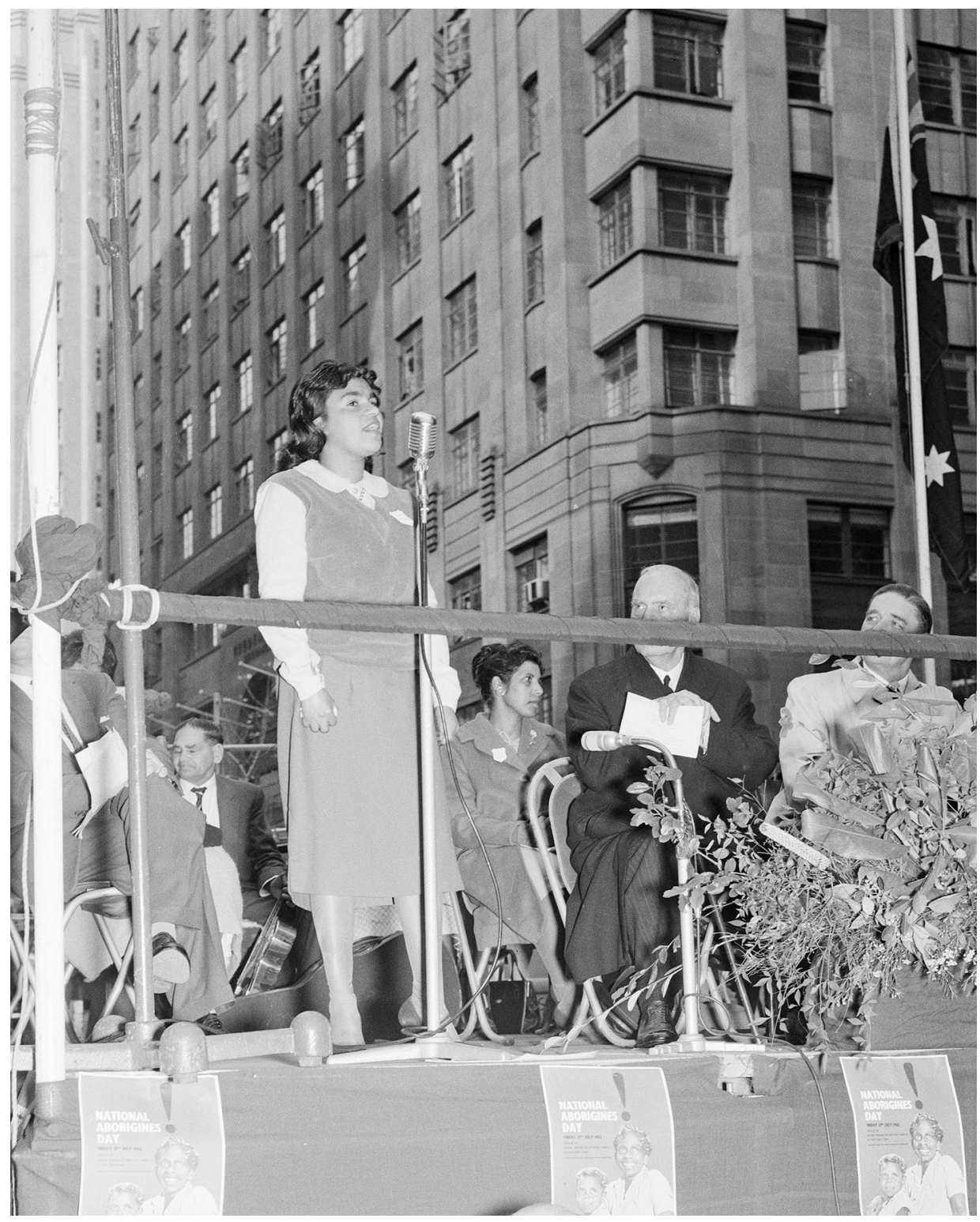

Figure 8: Eva Mumbler singing at the National Aborigines Day demonstration in Martin Place, Sydney, 13 July 1962.

Source: State Library of New South Wales, Government Printing Office 2-19991.

The participation of Aboriginal singers and musicians in the NADOC events produced a range of effects. On the one hand, it promoted the idea of 'successful Aborigines' as evidence of the government's success in pursuing the policy of assimilation. On the other hand, it presented Aboriginal people as celebrity-citizens producing commodities of cultural value to the postcolonial Australian nation. 
The classical repertoire performed by Harold Blair and Lorna Beulah provided one measure of success. However, the breadth of repertoire, including gospel, spirituals, popular song and country music incorporating Aboriginal forms, indicates the agency that Indigenous singers and musicians exercised in forging musical performances for National Aborigines Day. It also points to their impact on nonIndigenous audiences of the period. The white audiences' 'surprise' at the 'popular' style and 'modern values' of Aboriginal singers and musicians, which Jack Horner noted at National Aborigines Day in 1961, suggests that Aboriginal performers were engaging non-Indigenous audiences in unexpected ways, highlighting their limited understandings of contemporaneous Aboriginal life. Entertainers at National Aborigines Day in 1962 - including talent quest winners Lorna Beulah and Eva Mumbler, Joe Timbery's didjeridoo band and popular vocalists Jimmy Little and Col Hardy - 'captured the attention of more than 3,000 people who at one stage jammed Martin Place stopping all lunch-time traffic' ${ }^{88}$ By exceeding the narrative of assimilation that described them being passively 'accepted' into the mainstream, they became active in transforming interracial relations and sociality.

\section{Conclusion: Indigenous participation and the public sphere}

The first decade of National Aborigines Day is framed by the 'grassroots' political activism that led to the formation of the Federal Council for Aboriginal Advancement in 1958 and the citizenship referendum in 1967. This period encompasses a significant transition in interracial relations as the government-led policy of Indigenous assimilation to white Australia gave way to the increasing visibility of Aboriginal people and their movement into the public sphere. As we have argued, Indigenous activists, writers, singers and musicians played a vital role in this transition, through their participation in National Aborigines Day events, their success and self-promotion as celebrity citizens, and their deployment of activist discourse and Indigenous repertoire.

The focus of National Aborigines Day shifted in Sydney in 1966. The NSW NADOC was flagging in its organisational capacity and the demonstration planned for Martin Place did not go ahead. ${ }^{89}$ A concert was held in Hyde Park instead. It was organised by the newly established Foundation for Aboriginal Affairs and attracted a smaller crowd of 300 people. The theme was 'Education is the Key' and the Chief Secretary announced funding to 'ensure that all Aboriginal children have the opportunity to study at the secondary school level'..$^{0}$ For National Aborigines

88 'Crowds stood still in heart of Sydney', Dawn, August 1962: 1, 4.

89 Minutes, NADOC, 18 March 1966, 2 September 1966, NLA MS 3677.

90 “"Education the key” - Slogan for National Aborigines Day', Dawn, August 1966: 3. 
Day in 1967, a conference was held in the Sydney Town Hall, at which the Chief Secretary, the Lord Mayor and the Deputy Speaker of the Legislative Assembly, as well as 'prominent Aboriginal citizens', addressed an assembled audience of 2,500 secondary school pupils, university students and police cadets. ${ }^{91}$ Di Graham of the AAF, who joined NADOC at the time, describes the shift away from putting Aborigines 'up on show for just one day of the year' towards a new 'format', which intended to have an 'educational influence on both black and white Australians'. ${ }^{2}$

Two images illustrate this change in NADOC's first decade of promoting Aboriginal people and their repertoire in the public sphere. In 1959, Aboriginal schoolchildren from La Perouse performed folk dances from a British or European tradition, demonstrating their accomplishment for white dignitaries on the dais. In hindsight, it is an irredeemably assimilationist image. ${ }^{93}$ Folk dancing was repeated in 1960 but abandoned after that. By the mid-1960s, the educational perspective on interracial relations focuses on encounters between young people and the repertoire becomes a blend of the popular and Indigenous. An image from National Aborigines Day in 1966 illustrates this shift. It shows Dorothy Saunders, 17, of Greenacre, receiving 'instruction on the didgeridoo' from Michel Baluka, 19, of Milingimbi Island, off the coast of Arnhem Land. ${ }^{94}$ The following year, Australian students were assembled in their thousands to hear 'Aboriginal men, women and a school pupil' speak of 'their experiences and their views' and to enjoy well-known entertainers like Jimmy Little perform their latest hits. ${ }^{95}$

By the end of NADOC's first decade, the policy of assimilation was in question. Some Aboriginal people were looking beyond the putatively egalitarian nation-state to other sites of affiliation. Their increasingly transnational identifications mark a departure from NADOC's earlier conception of Aboriginal people as having 'no other community' and 'no other destiny' than that of assimilated Australian citizens. ${ }^{96}$ In 1968, National Aborigines Day established connections with other first nations peoples. At a NADOC meeting on 6 December 1967, Charles Perkins moved a motion proposing that the 1968 National Aborigines Day feature a 'panel of experts' including 'a Red Indian, an Eskimo and a Maori' who would be invited to Australia to 'confer with leading Aborigines'. ${ }^{97}$ After the 1967 referendum, Aboriginal participation in directing NADOC was acknowledged as a necessity by some non-Indigenous people. In providing funds for National Aborigines

\footnotetext{
91 'Australian conscience on Aborigines disturbed - Minister', SMH, 15 July 1967: 8.

92 Graham 1983: 156.

93 'Joyce Tilbury (left) and Sandra Stewart, pupils of La Perouse Public School, joined hands to lead a folk dance in Martin Place, where their school joined in celebrations to mark National Aborigines' Day', SMH, 11 July 1959: 1.

94 'Instruction on the didgeridoo: Before and after', Dawn, August 1966: 4.

95 Graham 1983: 156.

96 Rev. V.W. Coombes, Ministers' Bulletin 42, May 1959, NAA, A452, 1959/135.

97 Minutes, NADOC, 6 December 1967, SLNSW, MLMSS 4265.
} 
Day's activities in 1969, the Director of the Office of Aboriginal Affairs described the 'revitalised' objectives of National Aborigines Day as 'Aboriginal morale and community awareness'. ${ }^{98}$ In 1969, NADOC redrew the original 1956 constitution to include a clause providing for 'substantial Aboriginal participation in the direction of National and State committees' . ${ }^{99}$

As Steve Mickler observes, the 1960s witnessed the loss of government control over information about Aboriginal people in the public sphere. ${ }^{100}$ In its first decade, NADOC provided a platform for Aboriginal people to assert survival, broadcast their voices and perform their repertoire. Their presence in the public sphere had a dramatic impact on white subjectivity. The surprise that Jack Horner noted in 1961 was echoed by Ben Davie, a journalist covering National Aborigines Day in 1967. Davie described interviewing an Aboriginal man, Charles French, who made him realise that 'we would never have met, never talked, had this not been National Aborigines Week'. ${ }^{101}$ It was this profound systemic racialised disaggregation and the failure to acknowledge Aboriginal futurity that Indigenous participants and performers, in the first decade of National Aborigines Day, were challenging. As Kath Walker put it in the iconic poem she performed in 1965:

We want hope, not racialism,

Brotherhood, not ostracism,

Black advance, not white ascendance:

Make us equals, not dependents. ${ }^{102}$

\section{References}

\section{Archival sources}

\section{Australian Broadcasting Corporation}

ABC, TARA 350848, 'Segment - Aborigines Day', 14 July 1967

\section{Fairfax}

Fairfax FXT310206, 'Aboriginal singer Nancy Ellis arrives at Central Railway Station', Sun News photograph, 23 April 1953

98 B.G. Dexter to Minister-in-Charge, 30 April 1970, NAA, A2354, 1969/440.

99 Amended Constitution of National Aborigines Day Observance Committee, 24 November 1969, SLNSW MLMSS 4057.

100 Haebich 2008: 151 .

101 Ben Davie, 'A once-a-year thought for our Aborigines', 12 July 1967, news clipping, SLNSW, MLMSS 4265.

102 'Aboriginal Charter of Rights', Walker 1964: 9. 
ABORIGINAL HISTORY VOL 422018

Fryer Library, University of Queensland

UQFL84, The Papers of Oodgeroo Noonuccal, Box 30

\title{
National Archives of Australia
}

NAA, A452, 1957/2671, National Aborigines Day 1957 - (Production of booklet)

NAA, A452, 1959/135, National Aborigines Day 1959

NAA, A2354, 1969/440, National Aborigines Day 1970

\section{National Film and Sound Archive}

NFSA 21836, End of the Walkabout, 1958, documentary, directed by E.O. Stocker, Department of Territories, Australia

NFSA 283503, Gary Shearston, 1966, 'The Land Where the Crow Flies Backwards' and 'We Are Going to Freedom', sound recording, produced by Sven Libaek, Sydney

\section{National Library of Australia}

NLA MS 3677, National Aborigines Day Observance Committee (Australia), Records, 1964-1968

\section{State Library of New South Wales}

SLNSW, MLMSS 4057, Aboriginal Australian Fellowship, Box 13 (1959-1968, NADOC National Aborigines Day Observance Committee)

SLNSW, MLMSS 4265, Rev. A. W. Grant Papers 1958-1973, Box 1 (NSW Aborigines Day Committee)

SLNSW, MLMSS 4503, Add on 1822, Australian Board of Missions Further Records, Box 23, Folders 21/1 (Minutes of the National Aborigines Day Advisory Committee, 1956-1959) and 22/1 (Chairman's correspondence regarding Aborigines, 1952-1976, 1962-1976)

\section{Newspapers and journals}

\author{
The Age \\ The Argus (Melbourne) \\ $\mathrm{Biz}$ \\ Daily Mirror \\ Daily News (Perth) \\ Dawn \\ News (Adelaide) \\ Sun-Herald \\ The Sydney Morning Herald
}




\section{Published sources}

Aboriginal and Torres Strait Islander Commission 2003, 'History of NAIDOC', Journal of Australian Indigenous Issues 6(2): 38-39.

Andrews, Shirley 1966, 'A musical mixed marriage', Australian Tradition, June: 6.

Attwood, Bain 2003, Rights for Aborigines, Allen \& Unwin, Sydney.

AusStage, ausstage.edu.au (accessed 23 August 2017).

Bandler, Faith and Len Fox 1983, The Time Was Ripe: A History of the Aboriginal-Australian Fellowship (1956-69), Alternative Publishing Co-operative, Chippendale, NSW.

Casey, Bill 2008, 'Modernity denied: The case of Harold Blair's 1956 EP, Australian Aboriginal Songs', in Impact of the Modern: Vernacular Modernities in Australia 1870s-1960s, Robert Dixon and Veronica Kelly (eds), Sydney University Press, Sydney: 52-61.

Casey, Maryrose 2011, 'Performing for Aboriginal Life and Culture: Aboriginal Theatre and Ngurrumilmarrmiriyu', Australasian Drama Studies 59: 53-68.

Curthoys, Ann 2010, 'Paul Robeson's visit to Australia and Aboriginal activism, 1960', in Passionate Histories: Myth, Memory and Indigenous Australia, Frances Peters-Little, Ann Curthoys and John Docker (eds), ANU E Press and Aboriginal History Incorporated, Canberra: 163-84. doi.org/10.22459/PH.09.2010.08.

Department of Territories 1961a, One People, Department of Territories, Canberra.

Department of Territories 1961b, The Policy of Assimilation: Decisions of Commonwealth and State Ministers at the Native Welfare Conference, January 26th and 27th, 1961, Department of Territories, Canberra.

Duncan, Alan T. 1993, 'Blair, Harold (1924-1976)', Australian Dictionary of Biography, National Centre of Biography, The Australian National University, adb.anu.edu.au/ biography/blair-harold-9520/text16761, published first in hardcopy 1993 (accessed online 28 April 2017).

Graham, Di 1983, 'My memories of the Fellowship', in The Time Was Ripe, Faith Bandler and Len Fox (eds), Alternative Publishing Co-operative, Chippendale: 149-60.

Haebich, Anna 2008, Spinning the Dream: Assimilation in Australia 1950-1970, Fremantle Press, Fremantle, WA.

Harold 1994, documentary, directed by Stephen Thomas, Ronin Films, Australia.

Harrison, Kenneth 1975, Black Man, White World, Novalit Australia, Cheltenham, Victoria.

Horner, Jack 1983, 'The two Fellowships: The AAF and the Christian Church', in The Time Was Ripe, Faith Bandler and Len Fox (eds), Alternative Publishing Co-operative, Chippendale: $167-76$. 
Horner, Jack 2004, Seeking Racial Justice: An Insider's Memoir of the Movement for Aboriginal Advancement, 1938-1978, Aboriginal Studies Press, Canberra.

Jimmy Little’s Gentle Journey 2003, documentary, directed by Sean Kennedy, Indigo Films, Australia.

Kerin, Rani 2005, 'Charles Duguid and the Aboriginal Assimilation in Adelaide, 19501960: The Nebulous "Assimilation" Goal', History Australia 2(3): 85.1-85.17.

McGregor, Russell 2011, Indifferent Inclusion: Aboriginal People and the Australian Nation, Aboriginal Studies Press, Canberra.

Maynard, John 2007, Fight for Liberty and Freedom: The Origins of Australian Aboriginal Activism, Aboriginal Studies Press, Canberra.

National NAIDOC Secretariat, 'NAIDOC' 2017, www.naidoc.org.au (accessed 23 August 2017).

Perkins, Charles N. 1965, 'Student Action for Aborigines Report', in Federal Council for Advancement of Aborigines and Torres Strait Islanders, Reports and Resolutions of the 8th Annual Conference on Aboriginal Affairs, Telopea Park High School, Canberra, ACT, 16-18 April, AIATSIS MS 3759, Series 11, Item 3a: 47-48, aiatsis. gov.au/sites/default/files/docs/collections/freedom-ride/safa-report-charles-perkins.pdf (accessed 7 March 2018).

Rowse, Tim (ed.) 2005, Contesting Assimilation, API Network, Perth.

Taffe, Sue 2005, Black and White Together: FCAATSI the Federal Council for the Advancement of Aborigines and Torres Strait Islanders, 1958-1973, University of Queensland Press, St Lucia.

Taffe, Sue 2014, 'Joyce Clague', Collaborating for Indigenous Rights, National Museum of Australia, Canberra, indigenousrights.net.au/people/pagination/joyce_clague (accessed 7 March 2018).

Taylor, Diana 2003, The Archive and the Repertoire: Performing Cultural Memory in the Americas, Duke University Press, Durham, NC. doi.org/10.1215/9780822385318.

Walker, Clinton 2014, Buried Country: The Story of Aboriginal Country Music, Verse Chorus Press, Portland, Melbourne \& London.

Walker, Kath (Oodgeroo Noonuccal) 1964, We Are Going, Jacaranda Press, Brisbane. 
This text is taken from Aboriginal History, Volume 42, 2018, edited by Ingereth Macfarlane, published 2018 by ANU Press, The Australian National University, Canberra, Australia.

doi.org/10.22459/AH.42.2018.01 